\title{
Papers
}

\section{Adult height after long term treatment with recombinant growth hormone for idiopathic isolated growth hormone deficiency: observational follow up study of the French population based registry}

Jean-Claude Carel, Emmanuel Ecosse, Marc Nicolino, Maïté Tauber, Juliane Leger, Sylvie Cabrol, Irène Bastié-Sigeac, Jean-Louis Chaussain, Joël Coste

\begin{abstract}
Objective To evaluate the efficacy of recombinant growth hormone for increasing adult height in children treated for idiopathic isolated growth hormone deficiency.

Design Observational follow up study.

Setting Population based registry.

Participants All 2852 French children diagnosed as having isolated idiopathic growth hormone deficiency whose treatment started between 1987 and 1992 and ended before 1996 .

Main outcome measures Change in height between the start of treatment and adulthood; classification of patients according to whether treatment was completed as scheduled or stopped early.

Results Adult height was obtained for 2165 (76\%) patients. The mean dose of growth hormone at start of treatment was $0.42 \mathrm{IU} / \mathrm{kg} /$ week. Height gain was 1.1 (SD 0.9) standard deviation (SD) scores, resulting in an adult height of -1.6 (0.9) SD score (girls, 154 (5) $\mathrm{cm}$; boys, 167 (6) $\mathrm{cm}$ ). Patients who completed the treatment gained $1.0(0.7) \mathrm{SD}$ score of height in 3.6 (1.4) years. Patients with treatments stopped early gained $0.6(0.6)$ SD score in 2.7 (1.4) years while receiving treatment and a further $0.4(0.9)$ SD score after the end of treatment. Most of the variation in height gain was explained by regression towards the mean, patients' characteristics, and delay in starting puberty. Severe growth hormone deficiency was associated with better outcome. Each year of treatment was associated with a gain of $0.2 \mathrm{SD}$ score $(1.3 \mathrm{~cm})$.

Conclusion The effect of growth hormone is unclear in many patients treated for so called idiopathic isolated growth hormone deficiency. Most of the patients have pubertal delay and a spontaneous growth potential, which must be taken into account when measuring the effect and cost effectiveness of treatments. Growth hormone deficiency should be clearly distinguished from pubertal delay, and criteria should restrict the definition to patients with severely and permanently altered growth hormone secretion as our results support the use of growth hormone in
\end{abstract}

such patients. Long term trials are required for most patients currently treated.

\section{Introduction}

Idiopathic growth hormone deficiency is the indication for treatment in $50 \%$ of children receiving growth hormone, as reported for 100000 children worldwide in 1999. ${ }^{1}$ Growth hormone treatments aim to normalise growth, correct health problems associated with growth hormone deficiency, and help patients achieve an adult height in the normal range for the general population and for familial genetic potential. ${ }^{2-4}$

Growth hormone has been used for four decades, initially as an extract and now in recombinant form, but we still know little about its long term effects on adult height. ${ }^{1}$ No long term controlled trial has been performed, and evaluation of the effect of growth hormone is based on comparisons with historical controls or on changes in height. ${ }^{5}$ Growth hormone deficiency is poorly defined and ranges from severe to borderline. The issue of diagnostic criteria for growth hormone deficiency has been widely considered, ${ }^{7-11}$ but profiles of patients treated around the world do not always fit the strict definitions, with little change in profile over time. Long term follow up is needed to provide data on adult height. Adult heights are generally recorded for patients who have been followed over a long period, but not for patients who stop treatment prematurely, therefore results can be biased. ${ }^{12}$

Most published studies have reported the short term (1 to 2 years) effects of growth hormone. Most results from long term studies published in the 1990s concern small groups of patients. ${ }^{1}$ Cooperative studies have reported results for a small proportion $(<5 \%)$ of the patients enrolled; analyses are therefore prone to selection bias. ${ }^{13-15}$

From 1973 to 1997 , every prescription of growth hormone in France had to be approved by a central agency (Association France-Hypophyse). This facilitated the collection of data from a population based cohort of patients.

In 1997, we presented data for height for 1700 patients, $55 \%$ of whom had received growth hormone
Editorial by Saenger

Groupe hospitalier Cochin-Saint

Vincent de Paul and Faculté

Cochin-Université

Paris V, 75014 Paris, France

Department of

Paediatric

Endocrinology and INSERM U561

Jean-Claude Carel

professor of

paediatrics

Jean-Louis

Chaussain

professor of

paediatrics

Irène Bastié-Sigeac

clinical research

associate

Department of Biostatistics

Emmanuel Ecosse

statistician

Joël Coste

associate professor of

biostatistics

Department of

Paediatric

Endocrinology,

Hôpital Robert

Debré, 75019 Paris

Juliane Leger

associate professor of

paediatrics

Paediatric

Endocrinology

Unit, Hôpital

Trousseau, 75571

Paris

Sylvie Cabrol

associate professor of

paediatrics

continued over

bmj.com 2002;325:70 

Paediatric

Endocrinology,

Hôpital Debrousse

Marc Nicolino

associate professor of

paediatrics

Department of Paediatric

Endocrinology,

Hôpital des Enfants,

31026 Toulouse,

France

Maït Tauber

professor of

paediatrics

Correspondence to:

J-C Carel

carel@cochin.

inserm.fr
Department of

Lyon, 69322 France

of human origin. ${ }^{12}$ We then collected data on adult height of patients treated solely with recombinant growth hormone for idiopathic isolated growth hormone deficiency.

\section{Participants and methods}

\section{Participants}

Our present study included all French children who were diagnosed with isolated idiopathic growth hormone deficiency whose treatments began between 1 July 1987 and 31 December 1992 and who had attained adult height by September 1999 (fig 1).

We identified patients as having growth hormone deficiency according to the criteria used at the time, which included data on height, two growth hormone stimulation tests, or assessment of spontaneous growth hormone secretion. ${ }^{12}$ Growth hormone assays were performed by the centres where children were receiving treatment. For analysis, patients were assigned to one of three categories according to the initial assessment of growth hormone secretion: classical growth hormone deficiency if the peak of the two growth hormone stimulation tests was below $10 \mu \mathrm{g} / \mathrm{l}$, neurosecretory dysfunction if peak growth hormone concentration was $>10 \mu \mathrm{g} / \mathrm{l}$ but spontaneous growth hormone secretion was low, and inadequate criteria if the patient had been considered growth hormone deficient but the criteria were not met. Sex steroid priming was used before growth hormone testing in $2 \%$ of patients.

Data collected

At baseline and follow up visits (every three to six months), paediatric endocrinologists recorded the

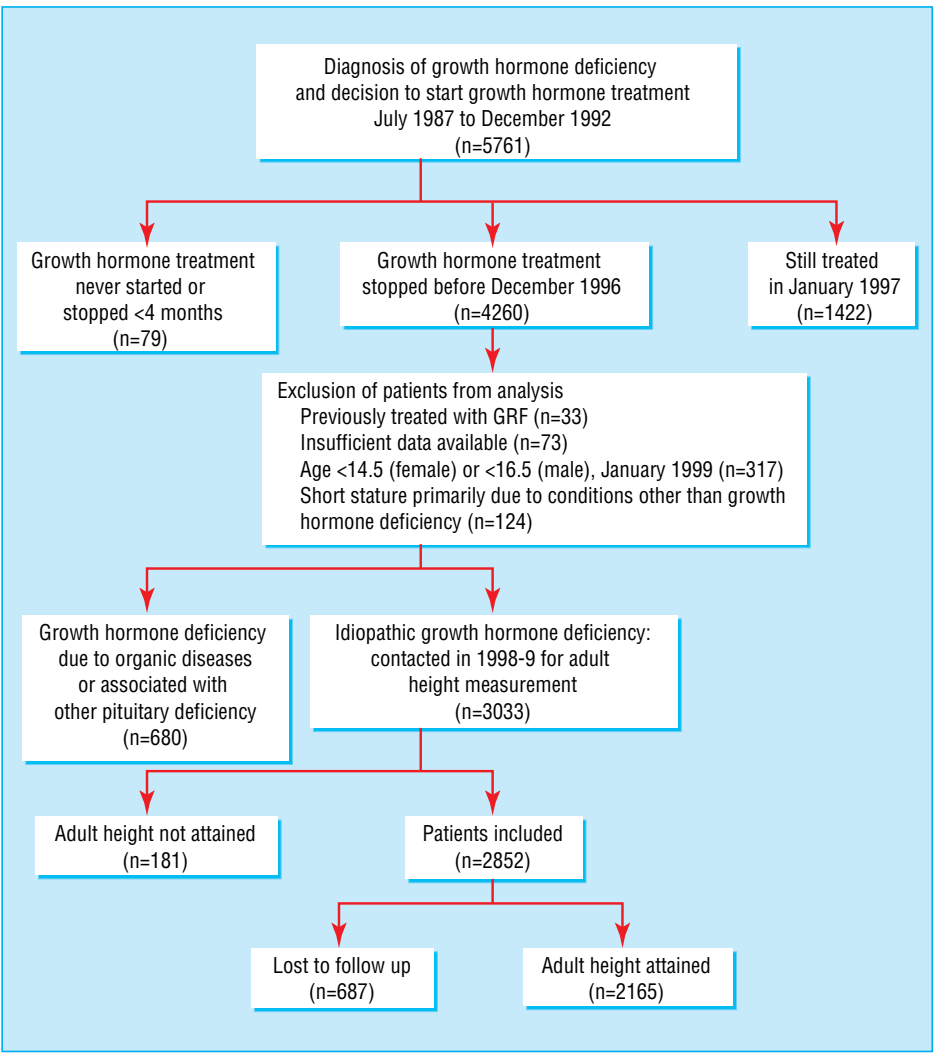

Fig 1 Description of cohort. GRF=growth hormone releasing factor
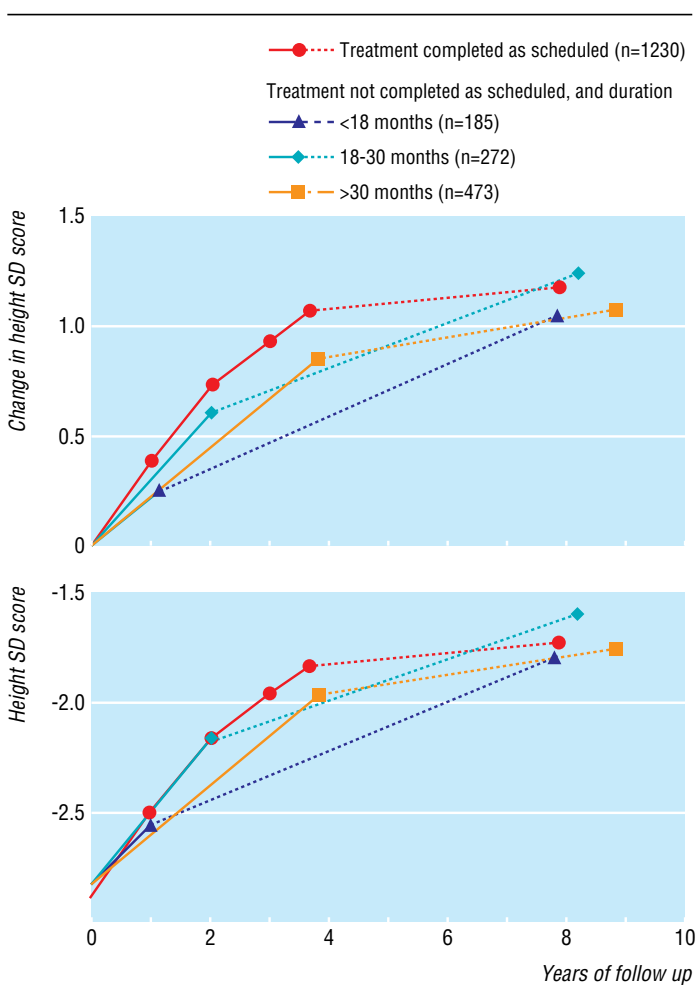

Fig 2 Changes in height in standard deviation (SD) score in patients treated with growth hormone, relative to beginning of treatment (top) and in absolute values. Solid line indicates treatment; broken line indicates end of treatment to attainment of adult height

height, weight, age, bone age ${ }^{16}$ and pubertal stage of the patients, ${ }^{17} 18$ together with the dose of growth hormone they were taking, the frequency of injections, and any associated treatments. The Association France Hypophyse decided annually whether the treatment should be continued. Criteria for discontinuation of treatment (scored as completion) were growth velocity $<3 \mathrm{~cm}$ /year, bone age $\geqslant 13$ years (girls) or $\geqslant 15$ years (boys), or height $\geqslant 160 \mathrm{~cm}$ (girls) or $\geqslant 170 \mathrm{~cm}$ (boys). The third criterion applied to 30 of the 2852 patients $(1.1 \%)$.

We prospectively collected follow up data in 1998-9 from doctors or from patients who provided "self reported" values for height and weight. We considered that adult height had been attained if growth velocity was $\leqslant 1 \mathrm{~cm}$ /year or if bone age was $\geqslant 16$ years (girls) or $\geqslant 18$ years (boys) $\left(99.6 \%\right.$ of adult height). ${ }^{19}$ If data on bone age were not available, bone age was estimated from previous measurement(s). ${ }^{13}$ We obtained adult heights for 2165 patients (75.9\% of 2852), 335 (15\%) of which were self reported.

\section{Analysis of growth and statistical methods}

We calculated standard deviation (SD) scores of height and weight for age, sex, or gestational age, and target height. ${ }^{12}$ Age at onset of puberty was expressed in standard deviations. ${ }^{17} 18$ We calculated growth hormone dose in $\mathrm{IU} / \mathrm{kg} /$ week and used the data to construct regression equations: dose $=$ initial $\operatorname{dose}+K$ time, where $K$ is the slope of the change in dose.

We constructed, in several stages, a model for predicting adult height. ${ }^{5}{ }^{20}$ We grouped the potential predictors into those accounting for regression 
towards the mean, those describing genetic growth potential, those describing the child at baseline, and those describing growth hormone and associated treatments (see table 3). We tested variables in each group as predictors of outcome after adjusting for variables identified at previous stages. These predictors were included in a final model (table 4). The main outcome response-the difference between adult and baseline heights (standard deviation scores)-was approximately normally distributed. Two potential predictors (initial dose of growth hormone and maximum stimulated peak level of growth hormone) were $\log$ transformed to yield normally distributed variables. As all models were adjusted for baseline height, they describe adult height gain - that is, the difference between adult and baseline height expressed in standard deviations - and adult height itself (in standard deviations). ${ }^{5}$ We used the SAS statistical package for analysis.

\section{Results}

Characteristics of participants at baseline and treatments

At a mean age of 13.3 years (boys) and 11.6 years (girls), 1178/1836 (64\%) boys and 677/1016 (66\%) girls were prepubertal, indicating pubertal delay (table 1). These initially prepubertal patients entered puberty late, at 14.1 (SD 1.5) years (boys) and 12.5 (1.3) years (girls) (0.9 (1.3) SD score). The mean dose of growth hormone at start of treatment was $0.42 \mathrm{IU} / \mathrm{kg} /$ week (0.29 to $0.62 \mathrm{IU} / \mathrm{kg} /$ week in $90 \%$ of the patients). Puberty inhibitors were used in 237 (8.3\%) patients. Sex steroids were used in $132(4.6 \%)$ patients, at a mean age of 15.2 (2.2) years (boys) and 12.9 (2.1) years (girls).

\section{Changes in height}

We classified patients according to whether treatment was completed $(1524,53.4 \%)$ or stopped early (table 2$)$. When treatment was completed, the height gain was $1.0(0.7) \mathrm{SD}$ in a total of 3.6 (1.4) years; most of the height was gained during the first two years (fig 2 ). If treatment was stopped early, the height gain was significantly smaller (see fig 2 - for example, during the first year of treatment, $0.38(0.39) \mathrm{SD} v 0.31(0.37)$ $\mathrm{SD}$ in the patients who completed or stopped the treatment, respectively; $\mathrm{P}=0.0003$ ). Normal results in retests of growth hormone secretion were the reason for non-completion in $14 \%$. Pubertal girls were the most likely to complete the treatment $(272 / 339,80 \%)$, prepubertal boys the least likely (485/1186, 41\%).

Adult height was recorded in $81 \%$ and $70 \%(1232 /$ 1524 and 933/1328) of patients who completed treatment and patients who did not, respectively. After growth hormone treatment, patients who completed treatment gained $2.8(2.8) \mathrm{cm}$, and those who did not complete treatment gained $12.3(8.0) \mathrm{cm}$. Mean adult height was therefore similar (-1.6 SD), 0.4 SD below target height.

\section{Predictive models for adult height}

The continued increase in height after early termination of growth hormone treatment indicated that changes in height standard deviation scores were not necessarily directly due to growth hormone. Growth is a multifactorial process and baseline differences
Table 1 Baseline characteristics and details of growth hormone therapy for the children in the study. Values are mean (SD) unless otherwise specified

\begin{tabular}{|c|c|c|}
\hline & Boys & Girls \\
\hline No of patients & 1836 & 1016 \\
\hline Chronological age (years) & $13.2(2.2)$ & $11.6(1.9)$ \\
\hline Bone age (years) & $10.6(2.3)$ & $9.5(2.0)$ \\
\hline Height (SD score) & $-2.6(0.7)$ & $-2.8(0.8)$ \\
\hline Growth velocity (cm/year) & $4.5(1.7)$ & $4.7(1.7)$ \\
\hline Growth velocity (SD score) & $-0.8(1.4)$ & $-0.9(1.9)$ \\
\hline Target height (SD score) & $-1.2(1.0)$ & $-1.1(1.0)$ \\
\hline Weight (SD score) & $-1.5(0.8)$ & $-1.5(0.9)$ \\
\hline \multicolumn{3}{|l|}{ Pubertal stage: } \\
\hline No (\%) prepubertal & $1178(64)$ & $677(66)$ \\
\hline No (\%) pubertal & $658(36)$ & $339(34)$ \\
\hline \multicolumn{3}{|l|}{ Severity of the deficiency (\%): } \\
\hline Maximum peak GH concentration $<3 \mu \mathrm{g} / \mathrm{l}$ & 4 & 3 \\
\hline Maximum peak GH concentration $\geqslant 3 \mu \mathrm{g} / \mathrm{l}$ and $<7 \mu \mathrm{g} / \mathrm{l}$ & 23 & 23 \\
\hline Maximum peak GH concentration $\geqslant 7 \mu \mathrm{g} / \mathrm{l}$ and $<10 \mu \mathrm{g} / \mathrm{l}$ & 48 & 48 \\
\hline Neurosecretory dysfunction & 9 & 10 \\
\hline Inadequate criteria for GH deficiency & 16 & 16 \\
\hline Maximum GH stimulated peak concentration $\left(\mu \mathrm{g} / \mathrm{l}^{*}\right.$ & $8.6(3.6)$ & $8.7(3.5)$ \\
\hline No (\%) treatment completed as scheduled & $851(46)$ & $673(66)$ \\
\hline Age on 1 January 1999 & $22.2(2.4)$ & $20.3(2.2)$ \\
\hline Treatment duration (year) & $3.2(1.5)$ & $3.2(1.4)$ \\
\hline \multicolumn{3}{|l|}{ Year of treatment start (No (\%)): } \\
\hline $1987-8$ & $427(23)$ & $167(16)$ \\
\hline $1989-90$ & $877(48)$ & $481(47)$ \\
\hline $1990-1$ & $532(29)$ & $368(36)$ \\
\hline \multicolumn{3}{|l|}{ Growth hormone dose: } \\
\hline Initial dose (IU/kg/week) & $0.42(0.11)$ & $0.43(0.11)$ \\
\hline Slope of changes in dose (IU/kg/week/year) & $-0.01(0.05)$ & $-0.01(0.05)$ \\
\hline Mean number of GH injections over the treatment period (No/week) & $5.7(0.9)$ & $5.7(0.8)$ \\
\hline \multicolumn{3}{|l|}{ No (\%) associated treatment: } \\
\hline Sex steroids at the time of puberty & $115(6)$ & $17(2)$ \\
\hline Puberty inhibitors $\dagger$ & $128(7)$ & $109(11)$ \\
\hline
\end{tabular}

$\mathrm{SD}=$ standard deviation

${ }^{*}$ Median (interquartile range).

tWhen given for at least six months.

between patients who completed treatment and those that did not may hinder comparison. Therefore, we constructed a multivariate model of factors explaining adult height (table 3). In the final model (table 4), target height and birth weight and regression towards the mean accounted for $33 \%$ of outcome variance. Variables determined at baseline that predicted a good outcome were age, bone age delay, and prepubertal status. Thus, older patients presenting no signs of puberty and with marked bone age delay had better outcomes. A negative association with male sex reflected sex dependent differences in pubertal age. Severe growth hormone deficiency was associated with better outcome. Whether or not treatment was completed, and length of treatment were independent predictors. Patients who did not complete the study grew 0.3 SD more than those who did; conversely, duration of treatment was positively associated with outcome (0.2 SD per year of treatment). Growth hormone dose did not predict adult height. Together, all variables associated with treatment accounted for $4.5 \%$ of outcome variance.

In a separate analysis (1048 prepubertal patients for whom the onset of puberty could be recorded), age at onset of puberty was positively associated with outcome and accounted for $5 \%$ of outcome variance. The proportion of patients entering puberty was higher for completers than for non-completers at an 
equivalent time point (fig 3). Thus, response is related to treatment, its completion, and the onset of puberty.

\section{Discussion}

We found that children treated for idiopathic growth hormone deficiency had a mean adult height $8-10 \mathrm{~cm}$ below that of the general population and did not reach their target height. Children who stopped treatment early continued to grow and reached similar adult heights to patients who completed treatment. Pubertal delay accounted for a large proportion of the catch-up growth observed, and children with severe growth hormone deficiency had better outcomes than children with borderline diagnoses.

\section{Strengths and weaknesses of the study}

Studies generally assess change in height and assume that all improvement results directly from treatment. We did not select our sample according to outcome. Instead, we studied all children who started treatment; in this population, growth continued in children who stopped treatment before the end of growth. Multivariate analysis showed that patients who did not complete the treatment did better, and that length of treatment was positively associated with outcome. Patients who completed the treatment generally had more severe growth hormone deficiency and increased in height with longer treatments. Patients who do worse initially stop treatment and finally do as well. Our results are consistent with completion bias, analogous to indication bias, in which more severely affected patients

Table 2 Changes in height in subgroups of patients receiving growth hormone treatment. Values are means (SD) unless otherwise specified

\begin{tabular}{|c|c|c|}
\hline & $\begin{array}{l}\text { Treatment completed } \\
\text { as scheduled }\end{array}$ & $\begin{array}{l}\text { Treatment stopped } \\
\text { early }\end{array}$ \\
\hline \multicolumn{3}{|l|}{ Baseline: } \\
\hline No (\% boys) of patients & $1524(56)^{\star *}$ & $1328(74)$ \\
\hline Age (years) & $12.9(2.1)^{\star *}$ & $12.3(2.3)$ \\
\hline No (\% boys) prepubertal & $881(55)^{* \star}$ & $974(72)$ \\
\hline No pubertal boys & 371 & 287 \\
\hline No pubertal girls & 272 & 67 \\
\hline Bone age (years) & $10.6(2.2)^{\star *}$ & $9.8(2.4)$ \\
\hline Height (SD score) & $-2.7(0.8)$ & $-2.7(0.8)$ \\
\hline Weight (SD score) & $-1.4(0.9)^{*}$ & $-1.6(0.8)$ \\
\hline Growth velocity (cm/year) & $4.8(1.8)^{* \star}$ & $4.4(1.5)$ \\
\hline Peak GH concentration $(\mu \mathrm{g} / \mathrm{l}) \dagger$ & $8.5(3.6)^{\star}$ & $8.8(3.5)$ \\
\hline Target height (SD score) & $-1.1(1)$ & $-1.2(1)$ \\
\hline \multicolumn{3}{|l|}{ End of treatment: } \\
\hline No & 1524 & 1328 \\
\hline Age (years) & $16.6(1.5)$ & $15(2.1)$ \\
\hline Duration of treatment (years) & $3.6(1.4)$ & $2.7(1.4)$ \\
\hline Height (SD score) & $-1.7(0.8)$ & $-2.1(0.9)$ \\
\hline Height (cm) (boys/girls) & $163(6) / 151(5)$ & $152(11) / 141(10)$ \\
\hline Change in height (SD score) & $1.0(0.7)$ & $0.6(0.6)$ \\
\hline \multicolumn{3}{|l|}{ Adult height: } \\
\hline No (\% of patients at baseline) & $1232(81)$ & $933(70)$ \\
\hline Age (years) & $20.8(2.9)$ & $20.9(2.6)$ \\
\hline Total duration of follow up (years) & $7.9(2.2)$ & $8.5(1.7)$ \\
\hline Height (SD score) & $-1.6(0.9)$ & $-1.5(1)$ \\
\hline Height (cm, boys/girls) & $167(6) / 154(5)$ & $167(6) / 154(6)$ \\
\hline Change in height from end of treatment (SD score) & $0.1(0.5)$ & $0.4(0.9)$ \\
\hline Change in height from baseline (SD score) & $1.1(0.9)$ & $1.1(1)$ \\
\hline
\end{tabular}

$\mathrm{SD}=$ standard deviation.

Comparisons at baseline with patients who stopped treatment early (Student's $t$ test and Kruskall-Wallis test for peak $\mathrm{GH}, \mathrm{P}<0.01$ considered to be significant, given the number of comparisons performed): ${ }^{*} \mathrm{P}<0.001$; ${ }^{* *} P<0.0001$.

†Median (interquartile range) receive heavier treatment. ${ }^{21}$ Overall, treatment of a child for 3.2 years was associated with an estimated mean height gain of $4.2 \mathrm{~cm}$.

We should also consider methodological aspects, such as whether the diagnosis of growth hormone deficiency was valid in our study population. The main criterion for a diagnosis of growth hormone deficiency in short children in the 1990 s was a peak growth hormone value, measured in two stimulation tests, of $<10$ $\mu \mathrm{g} / \mathrm{l} .{ }^{11}{ }^{22-24}$ However, this cut off has recently been questioned. $^{24}$ Sex steroid priming before growth hormone testing increases growth hormone secretion and may prevent the incorrect diagnosis of growth hormone deficiency, especially if puberty is delayed. ${ }^{25}$ Only $2 \%$ of our patients were primed with sex steroids, and priming would have increased growth hormone secretion in many of the others. Growth velocity is an important diagnostic criterion ${ }^{26-28}$ but was only slightly reduced in our patients compared with normative values for age and sex. However, these patients are typical of patients treated worldwide for growth hormone deficiency. All data were obtained from routine examination in daily practice and various growth hormone tests and assays were used, therefore their reliability may be questioned.

Finally, we selected a subgroup of the patients treated for growth hormone deficiency; patients with non-idiopathic growth hormone deficiency or abnormalities on pituitary magnetic resonance imaging were excluded, and patients with early onset growth hormone deficiency were excluded by the design of the study focusing on adult height. Therefore, our findings cannot be generalised to other patient populations.

\section{Comparison with other studies}

Our patients data are similar to patients in other studies in terms of age and height standard deviation scores at the start of treatment (tables 5 and 6). ${ }^{23} 2930$ The growth hormone doses used were $20 \%$ lower than those used in other European countries at the time but are unlikely to explain the differences found because growth hormone dose did not predict outcome. ${ }^{29} \mathrm{We}$ followed $76 \%$ of our target population, whereas other reports focused on a smaller proportion (1.9\% to $3.5 \%)$ of the patient sample. Such selection may focus on patients who responded well to treatment, providing an overoptimistic view of the results (fig 2). This probably explains the $15 \%$ to $30 \%$ difference from other studies. Our study design also enabled us to take into account the potential for spontaneous catch up of patients treated.

\section{Influence of pubertal delay}

Overall, the onset of puberty was delayed considerably in our patients, as in the Pharmacia International Growth Database, ${ }^{31}$ and variables linked to pubertal delay positively were associated with adult height. This strongly suggests that many had constitutional delay in growth and puberty, which should not be confused with growth hormone deficiency. ${ }^{25} 32$

\section{Conclusion}

Long term treatment with growth hormone has no clearcut benefit in a large proportion of patients treated for so called idiopathic isolated growth hormone deficiency. Most of the patients actually have pubertal delay and a potential for spontaneous catch 


\begin{tabular}{|c|c|c|}
\hline Variable & Regression coefficient ${ }^{*}$ & $P$ value \\
\hline \multicolumn{3}{|l|}{ Variables for regression towards the mean } \\
\hline Height at baseline (SD score) $\dagger$ & -0.45 & $<0.0001$ \\
\hline Duration of follow up from baseline to adultt & 0.06 & $<0.0001$ \\
\hline Interaction of height and duration $\dagger$ & 0.01 & 0.21 \\
\hline \multicolumn{3}{|l|}{ Patients' characteristics tested individually with previous variables ( $(t)$ as adjustment covariates } \\
\hline Sex $($ male $=1$, female $=0) \dagger$ & 0.14 & 0.0005 \\
\hline Birth weight (SD score) $\dagger$ & 0.21 & $<0.0001$ \\
\hline Target height (SD score) $\dagger$ & 0.36 & $<0.0001$ \\
\hline Birth height (SD score) & 0.20 & $<0.0001$ \\
\hline \multicolumn{3}{|l|}{ Baseline variables tested individually with previous variables ( $t$ ) as adjustment covariates } \\
\hline \multicolumn{3}{|l|}{ Baseline measurements: } \\
\hline Age (years) $\dagger$ & 0.16 & $<0.0001$ \\
\hline Weight (SD score) $\dagger$ & -0.25 & $<0.0001$ \\
\hline Pubertal $(\mathrm{yes}=1, \mathrm{no}=0) \dagger$ & 0.12 & 0.0017 \\
\hline Bone age delay (years) $\dagger$ & 0.23 & $<0.0001$ \\
\hline Log peak growth hormone concentration $(\mu \mathrm{g} /) \dagger$ & -0.07 & 0.025 \\
\hline Growth velocity (SD score) & 0.04 & 0.001 \\
\hline Interaction between age and sex & 0.01 & 0.66 \\
\hline Interaction between growth velocity and log peak growth hormone concentration & 0.07 & 0.0003 \\
\hline Interaction between target height and log peak growth hormone concentration & 0.01 & 0.50 \\
\hline \multicolumn{3}{|l|}{ Treatment and follow up variables tested individually with previous variables ( $t$ ) as adjustment covariates } \\
\hline Duration of treatment (years) $\dagger$ & 0.14 & $<0.0001$ \\
\hline Completion of treatment as scheduled (yes $\left.=1, \mathrm{n}_{0}=0\right) \dagger$ & 0.01 & 0.75 \\
\hline Log mean growth hormone dose (IU/kg/week) & 0.14 & 0.067 \\
\hline Log initial growth hormone dose (IU/kg/week) & 0.12 & 0.067 \\
\hline Change in growth hormone dose (IU/kg/week/year) & 0.28 & 0.37 \\
\hline No of injections/week & 0.03 & 0.11 \\
\hline Age at onset of puberty (SD score)‡ & 0.27 & $<0.0001$ \\
\hline Sex steroid treatment (yes $=1, \mathrm{no}=0$ ) & 0.12 & 0.092 \\
\hline Treatment with $\mathrm{GnRH}$ agonists (yes=1, no=0) & -0.08 & 0.13 \\
\hline Peak GH concentration at re-evaluation $(\mu \mathrm{g} / \mathrm{l})$ & 0.00 & 0.76 \\
\hline Adult height recorded by doctor $(1)$ or self reported $(0)$ & -0.04 & 0.32 \\
\hline Size of centre (in three groups, $<50,50-150$ or $\geqslant 150$ patients per centre) & 0.77 & 0.40 \\
\hline Interaction between ages at onset of puberty and completion of treatment & -0.04 & 0.10 \\
\hline Interaction between duration of treatment and completion of treatment & 0.02 & 0.44 \\
\hline Interaction between completion of treatment and peak growth hormone concentration at re-evaluation & 0.00 & 0.54 \\
\hline Interaction between completion of treatment and log mean growth hormone dose & 0.26 & 0.013 \\
\hline \multicolumn{3}{|c|}{$\begin{array}{l}\text { GnRH=gonadotropin releasing hormone; SD=standard deviation. } \\
\text { *Regression coefficient represents the change in SD score per unit change in predictor. } \\
\text { †Variables retained in final model. } \\
\text { fThis variable could be recorded with precision only in patients entering puberty during the course of treatment (not in patients who had already entered puberty by } \\
\text { the start of the treatment, nor in patients who stopped treatment early); therefore, it was not included in the final model. } \\
\text { Some of the variables that were individually associated with outcome during the construction of the model did not remain significant predictors after adjusting for } \\
\text { important covariates introduced at the next steps. }\end{array}$} \\
\hline
\end{tabular}

up, which must be taken into account when measuring the effect and cost effectiveness of growth hormone treatments. The diagnosis of idiopathic isolated growth hormone deficiency should be restricted to a small minority of patients with severely and permanently altered growth hormone secretion: our results support the use of growth hormone in such patients. We propose that peak growth hormone values should be below 2-4 $\mu \mathrm{g} / \mathrm{l}$, that sex steroid priming is used before growth hormone testing, and that more attention is paid to the causes of hypopituitarism.

Long term controlled trials to evaluate the effects of growth hormone treatment in patients who do not have growth hormone deficiency are needed, given the number of children treated worldwide. We should try to identify predictive markers for short stature in adults and focus intervention on patients at higher risk.

We thank Vean Eng Ly, Sabine Ximenes, and Dr Elisabeth Kind for their invaluable contributions. Drs Noel Cabet, Valérie Porra, Stéphane Chen, and Francine Mallet also participated in data collection. We also thank all the physicians involved in the follow up of patients and in the review process at Association France-
Table 4 Predictive factors for adult height gain in patients with growth hormone deficiency: final model

\begin{tabular}{|c|c|c|}
\hline Variable* & $\begin{array}{c}\text { Regression coefficient† } \\
(95 \% \mathrm{Cl})\end{array}$ & $P$ value \\
\hline No of patients in final modelł $\left(r^{2}\right)$ & $1885(0.58)$ & \\
\hline \multicolumn{3}{|l|}{ Patients' characteristics: } \\
\hline Target height (SD score) & $0.22(0.19$ to 0.25$)$ & $<0.0001$ \\
\hline Birth weight (SD score) & $0.11(0.08$ to 0.13$)$ & $<0.0001$ \\
\hline Sex (male $=1$, female $=0$ ) & $-0.54(-0.62$ to -0.47$)$ & $<0.0001$ \\
\hline \multicolumn{3}{|l|}{ Baseline variables: } \\
\hline Age (years) & 0.31 (0.28 to 0.33$)$ & $<0.0001$ \\
\hline Pubertal (yes $=1, \mathrm{no}=0$ ) & $-0.19(-0.26$ to -0.11$)$ & $<0.0001$ \\
\hline Bone age delay (years) & $0.18(0.15$ to 0.20$)$ & $<0.0001$ \\
\hline Weight (SD score) & $-0.19(-0.23$ to -0.14$)$ & $<0.0001$ \\
\hline Log peak growth hormone concentration $(\mu \mathrm{g} / \mathrm{l})$ & $-0.08(-0.13$ to -0.03$)$ & 0.002 \\
\hline \multicolumn{3}{|l|}{ Treatment variables: } \\
\hline Completion of treatment as scheduled (yes $=1, \mathrm{n} 0=0$ ) & $-0.30(-0.37$ to -0.22$)$ & $<0.0001$ \\
\hline Duration of treatment (years) & 0.22 (0.19 to 0.25$)$ & $<0.0001$ \\
\hline
\end{tabular}

$\mathrm{SD}=$ standard deviation.

${ }^{*}$ The model includes baseline height SD score, time interval between baseline and adult height measurements, and the interaction between these two variables; therefore, the model similarly predicts the factors for adult height itself (in SD).

†The regression coefficient represents the change in SD score per unit change in predictor.

‡The number of subjects corresponds to those with no missing value for any predictor variable. 

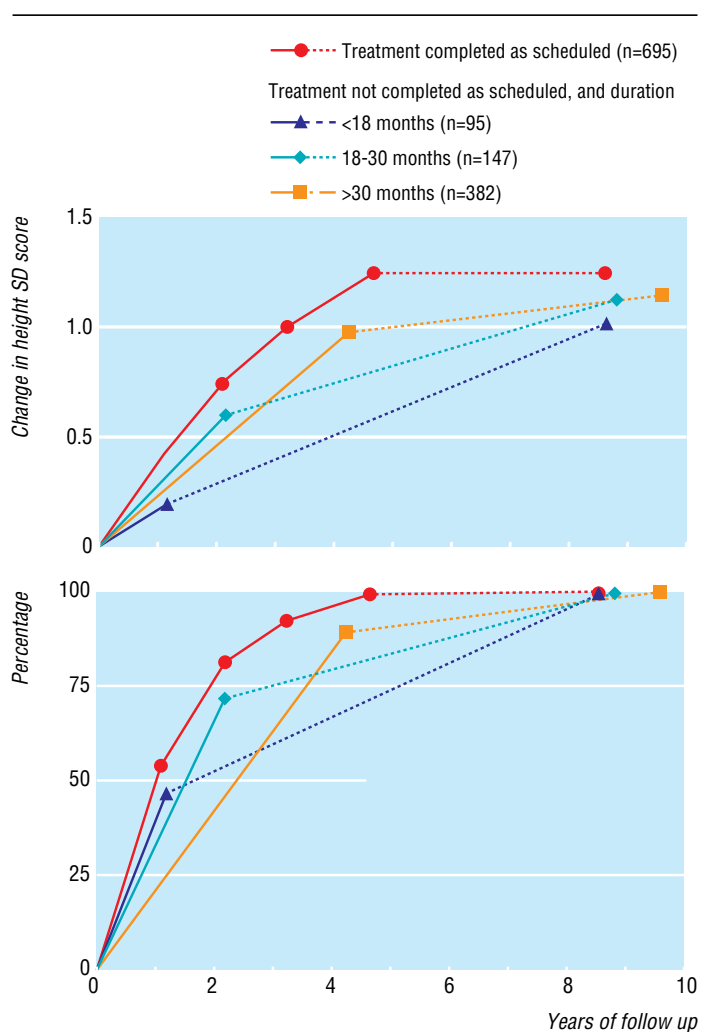

Fig 3 Changes in height in prepubertal patients treated with growth hormone (top) and proportion of patients who reached pubertal Tanner stage $2^{17-18}$ (bottom). Solid line indicates treatment; broken line indicates end of treatment to attainment of adult height

Hypophyse. The following clinicians were involved in the follow up of a large number of children in the study: Jacques Battin, Pascale Berlier, Michel Bost, Jean-Jacques Bouquier, Raja Brauner, Jacques Bringer, Jean-Pierre Charvet, Pierre Chatelain, Michel Colle, Paul Czernichow, Michel David, Francois Despert, Pierre-Andre Doyard, Herve Dubourg, Robert Dumas, Blandine Esteva, Christine Fedou, Anne Fjellestad-Paulsen, Patrick

Table 5 Comparison of baseline data from patients with idiopathic growth hormone deficiency from the present study with other published series

\begin{tabular}{|c|c|c|c|c|}
\hline Inclusion period & No & $\begin{array}{l}\text { Median age } \\
\text { (years) }\end{array}$ & $\begin{array}{l}\text { Median } \\
\text { height } \\
\text { (SD score) }\end{array}$ & $\begin{array}{l}\text { Max growth hormone } \\
\text { peak }(\mu \mathrm{g} / \mathrm{l})\end{array}$ \\
\hline \multicolumn{5}{|c|}{ Pharmacia International Growth Database } \\
\hline $1987-98^{23,29}$ & 12151 & 10.3 & -2.7 & 5.6 \\
\hline \multicolumn{5}{|l|}{ 1996-930: } \\
\hline United States & 1378 & 10.9 & -2.4 & 6.3 \\
\hline Elsewhere & 2459 & 10.6 & -2.4 & 6.5 \\
\hline This study* 1987-92 $^{*}$ & 5761 & 10.7 & -2.7 & 8.6 \\
\hline
\end{tabular}

$\mathrm{SD}=$ standard deviation.

*For comparison with other series, we have indicated the age at start of treatment for the entire group of 5761 patients (fig 1 ) and not for the subgroup evaluated to adult height.

Table 6 Comparison of adult height data from patients with idiopathic growth hormone deficency in the present study with other published series

\begin{tabular}{lccccc} 
& $\begin{array}{c}\text { No of patients } \\
\text { enrolled }\end{array}$ & $\begin{array}{c}\text { Age at } \\
\text { enrolment } \\
\text { (years) }\end{array}$ & $\begin{array}{c}\text { No of adult } \\
\text { heights reported } \\
\text { (\% of enrolled) }\end{array}$ & $\begin{array}{c}\text { Adult (or near } \\
\text { adult) height } \\
\text { (SD score) }\end{array}$ & $\begin{array}{c}\text { Change in } \\
\text { height } \\
\text { (SD score) }\end{array}$ \\
\hline $\begin{array}{l}\text { National Cooperative } \\
\text { Growth Study }\end{array}$ & 13876 & 11.5 & $258(1.9)$ & -1.4 & 1.3 \\
\hline $\begin{array}{l}\text { Pharmacia International } \\
\text { Growth Database }\end{array}$ & 10657 & 9.8 & $369(3.5)$ & -1.5 & 1.6 \\
\hline This study & 2852 & 12.6 & $2165(76)$ & -1.6 & 1.1 \\
\hline
\end{tabular}

$\mathrm{SD}=$ standard deviation.
What is already known on this topic

Large numbers of children are treated with recombinant growth hormone for so called idiopathic isolated growth hormone deficiency

The effect on adult height is unclear because of a lack of controlled trials and analysis, and that subgroups, rather than entire populations, are analysed.

\section{What this study adds}

Half the patients treated for idiopathic isolated growth hormone deficiency stop treatment before reaching adult height and achieve adult heights similar to those of patients who complete their treatment

Many patients diagnosed as having growth hormone deficiency actually have pubertal delay

A small proportion of patients with severe growth hormone deficiency respond better to treatment than patients with less severe growth hormone deficiency

Garandeau, Philippe Garnier, Christine Gendrel, François Girard, Micheline Gourmelen, Muriel Houang, Roger Jean, Monique Jesuran, Jean-Claude Job, Jean-Georges Juif, Yves Lebouc, Marcel Lecornu, Bruno Leheup, Anne Lienhardt, Jean-Marie Limal, Eric Mallet, Georges Malpuech, Roger Mariani, Catherine Naud-Saudreau, Isabelle Oliver, André Orsetti, Christian Pauwels, Marc Petrus, Catherine Pienkowski, Theresa Pierret, Michel Pierson, Graziella Pinto, Olivier Puel, Raphael Rappaport, Marie-Charles Raux-Demay, Denis Reiss, Pierre Rochiccioli, Bernard Sablayrolles, Charles Saab, Gilbert Simonin, Sylvie Soskin, Charles Sultan, Jean-Edmond Toublanc, and Jacques Weill.

Contributors: JCC and JC had the original idea for the study and organised it; MN, MT, JL, SC, IBS, and JLC participated in the design of the study or provided advice in presentation and interpretation of the results. EE was responsible for data analysis and model construction. All authors commented on earlier drafts and helped to interpret the findings. JCC and JC are the guarantors.

Funding: The study was supported by a grant from Programme Hospitalier de Recherche Clinique AOM96016.

Competing interests: Competing interests involving growth hormone manufacturers: J-CC, MN, MT, JL, SC, J-LC, and JC have been reimbursed for attending conferences; J-CC, MT, and J-LC have received fees for speaking; MT has received funds for research; J-LC has received fees for organising education; J-CC, MN, MT, JL, SC, and J-LC have been investigators in clinical trials sponsored by manufacturers. EE and IBS: no competing interests declared.

1 Guyda HJ. Commentary. Four decades of growth hormone therapy for short children: what have we achieved? J Clin Endocrinol Metab 1999;84:4307-16.

2 The drug and therapeutic committee of the Lawson Wilkins Pediatric Endocrine Society. Guidelines for the use of growth hormone in children with short stature. J Pediatr 1995; 127:857-67.

3 Vance ML, Mauras N. Drug therapy: growth hormone therapy in adult and children. N Engl J Med 1999;341:1206-16.

4 Brook CGD. Growth hormone: panacea or punishment for short stature? BMJ 1997;315:692-3.

5 Cole T. Methodology for the analysis of longitudinal height data during puberty. KIGS Report 1993;10:37-44.

6 Brook CGD, Kelnar CJH, Betts P. Controversy: which children should receive growth hormone treatment. Arch Dis Child 2000;83:176-8.

7 Rosenfeld RG, Albertsson-Wikland K, Cassorla F, Frasier SD, Hasegawa Y, Hintz RL, et al. Diagnostic controversy: the diagnosis of childhood growth hormone deficiency revisited. J Clin Endocrinol Metab 1995;80:1532-40.

8 Rosenfeld RG. Editorial: is growth hormone deficiency a viable diagnosis. J Clin Endocrinol Metab 1997;82:349-51. 
9 August GP. Symposium on controversies in the diagnosis of growth hormone deficiency. Pediatrics 1998;102:517

10 Saggese G, Ranke MB, Saenger P, Rosenfeld RG, Tanaka T, Chaussain JL, et al. Diagnosis and treatment of growth hormone deficiency in children Recombinant Human Growth Hormone Workshop held in Pisa, Italy, 27-28 March 1998. Horm Res 1998;50:320-40.

11 Guyda HJ. Commentary. Growth hormone testing and the short child. Pediatr Res 2000;48:579-80.

12 Coste J, Letrait M, Carel JC, Tresca J-P, Chatelain P, Rochiccioli P, et at. Long term results of GH treatment in short stature children: a population register-based study. BMJ 1997;315:708-13.

13 Blethen SL, Baptista J, Kuntze J, Foley T, LaFranchi S, Johanson A. Adult height in growth hormone $(\mathrm{GH})$-deficient children treated with biosynthetic GH. The Genentech Growth Study Group. J Clin Endocrinol biosynthetic GH. The Gen

14 Cutfield W, Lindberg A, Albertsson Wikland K, Chatelain P, Ranke MB, e al. Final height in idiopathic growth hormone deficiency: the KIGS experience. KIGS International Board. Acta Paediatr Suppl 1999;88:72-5

15 August GP, Julius JR, Blethen SL. Adult height in children with growth hormone deficiency who are treated with biosynthetic growth hormone: the National Cooperative Growth Study experience. Pediatric 1998;102:512-6.

16 Greulich WW, Pyle SI. Radiographic atlas of skeletal development of the hand and wrist. Stanford, CA: Stanford University Press, 1959

17 Marshall WA, Tanner JM. Variations in the pattern of pubertal changes in girls. Arch Dis Child 1969;44:291-303.

18 Marshall WA, Tanner JM. Variations in the pattern of pubertal changes in boys. Arch Dis Child 1970;45:13-24.

19 Bayley N, Pinneau S. Tables for predicting adult height from skeletal age. J Pediatr 1952;14:432-41.

20 Bland JM, Altman DG. Regression towards the mean. BMJ 1994;308:1499.

21 Weiss NS. Clinical epidemiology. The study of the outcome of illness. New York: Oxford University Press, 1986

22 Carel JC, Tresca J-P, Letrait M, Le Bouc Y, Job J-C, Chaussain JL, et al. Growth hormone testing for the diagnosis of growth hormone deficiency in childhood: a population register-based study. J Clin Endocrinol Metab 1997;82:2117-21.
23 Price DA. GH testing in KIGS: the clinical reality. In: Ranke MB, Wilton P, eds. Growth hormone therapy in KIGS-10 years' experience. Heidelberg. Johann Ambrosius Barth Verlag, 1999:73-80.

24 GH Research Society. Consensus. Consensus guidelines for the diagnosis and treatment of growth hormone (GH) deficiency in childhood and adolescence: summary statement of the GH research society. J Clin Endocrinol Metab 2000;85:3990-3.

25 Marin G, Domené HM, Barnes KM, Blackwell BJ, Cassorla FG, Cutler GB $\mathrm{Jr}$. The effects of estrogen priming and puberty on the growth hormone response to standardized treadmill excercise and arginine-insulin in normal girls and boys. J Clin Endocrinol Metab 1994;79:537-41.

26 Voss LD, Wilkin TJ, Bailey BJ, Betts PR. The reliability of height and height velocity in the assessment of growth (the Wessex Growth Study). Arch Dis Child 1991;66:833-7.

27 Van den Broeck J, Hokken-Koelega A, Wit J. Validity of height velocity as a diagnostic criterion for idiopathic growth hormone deficiency and Turner syndrome. Horm Res 1999;51:68-73.

28 Thakrar A, Taylor EM, Wales JK. Height velocity screening: the real world. J Public Health Med 1994;16:200-4.

29 Chatelain P. Trends in the diagnosis and treatment of short stature as revealed by KIGS. In: Ranke MB, Wilton P, eds. Growth hormone therapy in KIGS-10 years' experience. Heidelberg: Johann Ambrosius Barth Verlag, 1999;11-20.

30 Ranke MB, Geffner ME, Lindgren AC, Linberg A, Brown DM, Davenport $\mathrm{M}$, et al. The transatlantic gap: small differences in diagnoses-large differences in GH therapy [abstract]. Horm Res 2000;53(Suppl 2):47.

31 Ranke MB, Price DA, Albertsson-Wikland K, Maes M, Lindberg A. Factors determining pubertal growth and final height in growth hormone treatment of idiopathic growth hormone deficiency. Analysis of 195 Patients of the Kabi Pharmacia International Growth Study. Horm Res 1997;48:62-71.

32 Bourguignon JP. Linear growth as a function of age at onset of puberty and sex steroid dosage: therapeutic implications. Endocrine Rev 1988;9:467-88

(Accepted 11 December 2001) 